\section{Comparison of Acetic Acid to Glyphosate for Weed Suppression in the Garden}

\author{
Jacob C. Domenghini ${ }^{1}$
}

AdDITIONAL INDEX WORDs. garden establishment, organic garden, vinegar

SUMMARY. Interest in organic vegetable gardening has increased in recent years. Organic growers are searching for alternatives to glyphosate for weed suppression. This study was conducted twice. Each data collection period lasted 132 days during the growing seasons of 2016 and 2017 in Richmond, KY. Treatments included application of glyphosate, vinegar [ $5 \%$ acetic acid (AA)], 20\% horticulture grade vinegar (20\% AA), 30\% horticulture grade vinegar (30\% AA), and a negative control. Treatments were applied in a factorial arrangement with two application periods (fall and spring or spring only). The percentage of weed cover within plots was evaluated visually with a $0-10$ rating scale $(0=0 \%$ weeds or $100 \%$ of the plot is dead; $\mathbf{5}=\mathbf{5 0} \%$ weed growth; $10=\mathbf{1 0 0} \%$ of the plot is alive with weeds). All plots began the study with a rating of 10 . After the initial treatment applications, visual ratings of the $5 \%, 20 \%$, and $30 \%$ AA declined to a rating of 0 within 48 hours, whereas the glyphosate required 7 days $(P=0.05)$. Treatments were reapplied to part of the plots (subplots) in the spring when $\approx \mathbf{5 0 \%}$ of the plot had regrown with weeds. Glyphosate required 71 to 80.8 days to reach $50 \%$ regrowth and required only one retreatment. The $20 \%$ and $30 \%$ AA applications required three (2016) and four (2017) retreatments. Glyphosate has proven to be more effective at weed control in vegetable gardens when compared with vinegar, although $20 \% \mathrm{AA}$ and $30 \% \mathrm{AA}$ are viable alternatives.

$\mathrm{O}$ rganic vegetable growers have indicated that weed control is a challenge in organic crop production (Bond and Grundy, 2001; Stopes and Millington, 1991; Walz, 1999); therefore, it has become an important topic of research for organic growers (Radhakrishnan et al., 2002). Poor weed control results in lower vegetable and other agronomic crop yields (Gianessi and Reigner, 2007; Griffith et al., 2006; Peacock and Norton, 1990; Rowland et al., 1999). Synthetic herbicides cannot be used in organic production (Kuepper, 2002), and manual removal and cultivation are labor-intensive (Boyd et al., 2006; Gianessi and Reigner, 2007). A wide range of both synthetic and nonsynthetic broad-spectrum contact chemicals have been approved by the U.S. Department of Agriculture National Organic Program for

Received for publication 10 July 2019. Accepted for publication 1 Nov. 2019.

Published online 9 December 2019.

${ }^{1}$ Department of Agriculture, Eastern Kentucky University, A.B. Carter Building, 521 Lancaster Avenue, Richmond, KY 40475

J.C.D. is the corresponding author. E-mail: jacob. domenghini@eku.edu.

This is an open access article distributed under the $\mathrm{CC}$ BY-NC-ND license (https://creativecommons.org/ licenses/by-nc-nd/4.0/).

https://doi.org/10.21273/HORTTECH04453-19 weed control in organic systems (Kuepper, 2002), including vinegar (Garrett and Beck, 1999; Webber et al., 2005).

Previous studies have evaluated the efficacy of vinegar and other natural products to control weeds in vegetable crop and other agronomic production systems (Boyd et al., 2006; Evans et al., 2009; Radhakrishnan et al., 2002), as well as the effects that natural products have on the desired crop (Bingaman et al., 2000; Evans and Bellinder, 2009; Evans et al., 2011; Moran and Greenberg, 2008; Patton and Weisenberger, 2012). In addition to general weed control, natural controls for weeds at two growth stages were examined by Abouziena et al. (2009), and Brainard et al. (2013) studied the effectiveness of vinegar and clove oil applied at different temperatures, relative humidity, and weed growth stages.

In nonorganic production systems, glyphosate has been widely used as a broad-spectrum compound to control weeds globally (Malik et al., 1989). With conservation tillage systems, glyphosate is commonly applied before planting (Bruff and Shaw, 1992) and has been successful at controlling weeds with some residual control (Buhler and Werling, 1989; Wilson and Worsham, 1988). Several studies have evaluated the effectiveness of glyphosate at controlling weeds in crop production systems (Culpepper, 2006; Griffith et al., 2006; Norris et al., 2001; Shaw and Arnold, 2002), whereas others have compared glyphosate with natural products to control weeds (Abouziena et al., 2008; Patton and Weisenberger, 2012; Young, 2004).

Research of the use of natural products to control weeds before garden establishment with continued control throughout the growing season is limited. Additionally, research comparing the efficacy of weed suppression treatments applied in the fall for a spring garden compared to spring-only weed treatments is lacking. Therefore, to assist home gardeners or commercial farmers considering a transition from conventional to organic production systems, this study was undertaken to compare the effectiveness of three organic weedcontrol methods and that of glyphosate. Specific objectives of the study included: 1) evaluating the differences between spring and fall treatment applications and a spring-only treatment application; 2 ) evaluating the number of days after treatment (DAT) to $50 \%$ and $100 \%$ weed regrowth; and 3 ) evaluating the number of follow-up treatment applications required throughout the growing season.

\section{Materials and methods}

Preparation of Field plots AND INITIAL APPLICATION OF WEED CONTROL TREATMENTS. Field plots were identified in Oct. 2015 for the 2016 study and in Oct. 2016 for the 2017 study. Plots were located at the Eastern Kentucky University (EKU) Red Barn Garden (RBG) in

\begin{tabular}{llll}
\hline $\begin{array}{l}\text { Units } \\
\begin{array}{l}\text { To convert U.S. to SI, } \\
\text { multiply by }\end{array}\end{array}$ & U.S. unit & SI unit & $\begin{array}{l}\text { To convert SI to U.S., } \\
\text { multiply by }\end{array}$ \\
\hline 29.5735 & $\mathrm{fl} \mathrm{oz}$ & $\mathrm{mL}$ & 0.0338 \\
0.3048 & $\mathrm{ft}$ & $\mathrm{m}$ & 3.2808 \\
2.54 & inch $(\mathrm{es})$ & $\mathrm{cm}$ & 0.3937 \\
16.3871 & inch $^{3}$ & $\mathrm{~cm}^{3}$ & 0.0610 \\
$\left({ }^{\circ} \mathrm{F}-32\right) \div 1.8$ & ${ }^{\circ} \mathrm{F}$ & ${ }^{\circ} \mathrm{C}$ & $\left({ }^{\circ} \mathrm{C} \times 1.8\right)+32$
\end{tabular}


Richmond, KY (lat. $37^{\circ} 43^{\prime} 54.1^{\prime \prime} \mathrm{N}$, long. $\left.84^{\circ} 17^{\prime} 53.1^{\prime \prime} \mathrm{W}\right)$. The soil was a Caleast silt loam (fine, mixed, active, mesic Typic Hapludalfs). There were two treatment factors: 1) weed control \{glyphosate ( $1.6 \%$ a.i.), vinegar [5\% acetic acid (AA)], 20\% horticulture grade vinegar $(20 \% \mathrm{AA})$, and $30 \%$ horticulture grade vinegar $(30 \%$ AA)\}; and 2) treatment application timing [fall and spring (fall/spring) and spring only]. A summary of the weed control products is presented in Table 1. Plots were established in a randomized complete block design with three replicates of each treatment combination and an additional three control plots for a total of 27 plots. Plots measured $3 \times 3 \mathrm{ft}$ and were separated by $1.5-\mathrm{ft}$ borders that were not treated with weed control. Plots were located in a pasture that had been ungrazed, or in rest (Allen et al., 2010), for multiple years. A summary list of weeds that were growing in the pasture and plots is displayed in Table 2. Before the application of the initial weed control treatments in October of each year, the pasture area was cut to 3 inches with a rotary mower and plots were marked with stakes and string line. Treatments were not applied to the same plots in both studies; new plots were established adjacent to the first plots for the second year of the study.

In the fall before each study, all plots were mowed at 3 inches on 12 Oct. for the 2016 study and on 10 Oct. for the 2017 study. Weed control treatments were applied to only the fall/ spring plots $2 \mathrm{~d}$ after mowing (springonly plots were not treated in the fall). Clippings were raked and removed after mowing and before treatment applications. Glyphosate and 5\%, 20\%, and $30 \%$ AA treatments were applied to plots with $32-\mathrm{fl} \mathrm{oz}$ high-output spray bottles (The Bottle Crew, Farmington Hills, MI) labeled appropriately with each treatment. Treatments were applied by hand with spray bottles $\approx 12$ inches above the vegetation to ensure that all green, living weed tissue was covered on a spray-to-wet basis; vegetation was not sprayed to the point of runoff (Ragan and Massey, Inc., 2019). No data were collected in the fall following treatment application. In the spring, all plots were mowed at 3 inches on 21 Mar. 2016 and on 20 Mar. 2017. Only borders separating plots continued to be mowed at 3 inches following the initial mowing in March. Weed control treatments were applied to all plots (fall/spring and spring only) $2 \mathrm{~d}$ after mowing. Treatments were always applied on warm (65 to $\left.95{ }^{\circ} \mathrm{F}\right)$, sunny days. Data collection began the day after the initial treatments were applied on 24 Mar. 2016 and 23 Mar. 2017, and was continued for $132 \mathrm{~d}$ each year.

Plot ratings and treatment application. All plots were rated at $\approx 1000 \mathrm{HR}$. Initial plot ratings occurred daily for the first $10 \mathrm{~d}$ following treatment to determine how quickly each treatment killed all weeds in the plot. Ten DAT, all plots were tilled to a depth of 6 inches using a walk-behind $160-\mathrm{cm}^{3}, 17$-inch rear-tine dualrotating tiller (DRT900H; Husqvarna, Stockholm, Sweden) to simulate garden bed preparation for planting. Borders between plots were not tilled. After plots were tilled, each plot was rated two times per week. Plot ratings consisted of a visual evaluation of the percentage of weed cover within plots using a rating scale of 0 to $10(0=0 \%$ weeds or $100 \%$ of the plot is dead; $5=$ $50 \%$ weed growth; $10=100 \%$ of the plot is alive with weeds). A similar scale is used for evaluating turfgrass quality in the National Turfgrass Evaluation Program (NTEP) (Morris, 2000) and was adapted to evaluate the percentage of weed cover in each plot. A grid measuring $3 \times 3 \mathrm{ft}$ and constructed with half-inch PVC pipe for the frame and \#18 mason's line to create a 100square grid pattern was used to visually determine the percentage of weed cover within each plot.

All plots began the study with a rating of 10 . Following initial treatments, plots were divided in half, creating two subplots $(3 \times 1.5 \mathrm{ft})$ within each original plot. To simulate how a vegetable grower might continue to control weeds throughout the growing season, when the whole plot received a rating of $\geq 5$, the bottom subplot was retreated with the appropriate weed control chemical and the top subplot was left untreated. Thereafter, two ratings were recorded for each plot, a rating for the top subplot that only received the initial treatment and a rating for the bottom subplot that was retreated each time it received a rating of $\geq 5$.

Data analysis. Least-squares means of DAT for each plot to receive a rating of 0 , DAT until each subplot received a rating of $5(50 \%$ weed regrowth), DAT until each subplot received a rating of $10(100 \%$ weed regrowth), and number of retreatment applications needed for each subplot were analyzed. Means were compared among weed control treatments (glyphosate, 5\% AA, 20\% AA, and $30 \% \mathrm{AA}$ ) and treatment application timing (fall/spring and spring only).

All data were analyzed using the general linear model (GLM) procedure in SAS as a randomized complete block design with a $4 \times 2$ factorial arrangement of treatments (version 9.4; SAS Institute, Cary, NC). The experimental unit was the plot. Means were separated using Fisher's protected least significant difference at $P=0.05$.

\section{Results and discussion}

There was significant interaction between the two studies; therefore, data from each study are presented separately.

EfFects of treatments on wEEDs. After the initial treatment application, quality ratings of the $5 \%$, $20 \%$, and $30 \%$ AA treatments declined to a rating of 0 within $2 \mathrm{~d}$ (Table 3 ), indicating that all aboveground vegetation in the plots died. Plots treated with glyphosate required 6 to $7 \mathrm{~d}$ to receive a rating of 0 . Studies have shown that weed-control products

Table 1. Summary of the weed control products with active ingredients and manufacturer sources used during weed suppression studies in 2016 and 2017 in Richmond, KY.

\begin{tabular}{llcl}
\hline Weed control product & \multicolumn{1}{c}{ Product name } & Concn in spray solution & \multicolumn{1}{c}{ Product source or manufacturer } \\
\hline Acetic acid $(5 \%)$ & Great Value distilled white vinegar & Undiluted & Walmart, Bentonville, AR \\
Acetic acid $(20 \%)$ & Natural safe 20\% vinegar & Undiluted & Factory Direct Chemicals, Long Island, NY \\
Acetic acid $(30 \%)$ & Natural safe 30\% vinegar & Undiluted & Factory Direct Chemicals \\
Glyphosate & FarmWorks 41\% glyphosate plus & $1.6 \%$ a.i. & Ragan and Massey, Ponchatoula, LA \\
\hline
\end{tabular}


Table 2. List of weeds in the ungrazed pasture where treatment plots were located during weed suppression studies in 2016 and 2017 in Richmond, KY.

\begin{tabular}{lll}
\hline Common name & \multicolumn{1}{c}{ Scientific name } & Life cycle \\
\hline Redroot pigweed & Amaranthus retroflexus & Annual \\
Mouse-ear chickweed & Cerastium vulgatum & Perennial \\
Lamb's quarters & Chenopodium album & Annual \\
Field bindweed & Convolvulus arvensis & Perennial \\
Horseweed & Conyza canadensis & Annual \\
Yellow nutsedge & Cyperus esculentus & Perennial \\
Wild carrot & Daucus carota & Biennial \\
Tall fescue & Festuca arundinacea & Perennial \\
Ivyleaf morning glory & Ipomoea hederacea & Annual \\
Wood sorrel & Oxalis dillenii & Perennial \\
Narrow leaf plantain & Plantago lanceolata & Perennial \\
Blackseed plantain & Plantago rugelii & Perennial \\
Bulbous buttercup & Ranunculus bulbosus & Perennial \\
Carolina horsenettle & Solanum carolinense & Perennial \\
Johnson grass & Sorghum halepense & Perennial \\
Dandelion & Taraxacum officinale & Perennial \\
Red clover & Trifolium pratense & Perennial \\
White clover & Trifolium repens & Perennial \\
Thymeleaf speedwell & Veronica serpyllifolia & Perennial \\
\hline
\end{tabular}

Table 3. Mean number of days for vegetation in each treatment plot to die or receive a quality rating of 0 (0\% weeds) during the 2016 and 2017 growing seasons in Richmond, KY, following initial weed suppression treatment applications of $5 \%$ acetic acid (AA), $20 \% \mathrm{AA}, 30 \% \mathrm{AA}$, and glyphosate ( $1.6 \%$ a.i.).

\begin{tabular}{|c|c|c|c|c|c|c|c|c|}
\hline & \multicolumn{8}{|c|}{ Avg time for vegetation to receive a rating of 0 (d) } \\
\hline & \multicolumn{4}{|c|}{2016} & \multicolumn{4}{|c|}{2017} \\
\hline & \multicolumn{2}{|c|}{ Fall/Spring } & \multicolumn{2}{|c|}{ Spring only } & \multicolumn{2}{|c|}{ Fall/Spring } & \multicolumn{2}{|c|}{ Spring only } \\
\hline & Fall $^{\mathbf{z}}$ & Spring & Fally & Spring & Fall & Spring & Fall & Spring \\
\hline Control $^{\mathrm{x}}$ & - & - & - & - & - & - & - & - \\
\hline $5 \%$ AA & $1.67 \mathrm{~b}$ & $1.33 \mathrm{~b}$ & - & $1.67 \mathrm{~b}$ & $1.67 \mathrm{~b}$ & $1.67 \mathrm{~b}$ & - & $1.33 \mathrm{~b}$ \\
\hline $20 \% \mathrm{AA}$ & $1.33 \mathrm{~b}$ & $1.00 \mathrm{~b}$ & - & $1.33 \mathrm{~b}$ & $1.67 \mathrm{~b}$ & $1.67 \mathrm{~b}$ & - & $1.33 \mathrm{~b}$ \\
\hline $30 \% \mathrm{AA}$ & $1.00 \mathrm{~b}$ & $1.00 \mathrm{~b}$ & - & $1.00 \mathrm{~b}$ & $1.33 \mathrm{~b}$ & $1.00 \mathrm{~b}$ & - & $1.00 \mathrm{~b}$ \\
\hline Glyphosate & $6.67 \mathrm{a}$ & $7.00 \mathrm{a}$ & - & $7.33 \mathrm{a}$ & $7.67 \mathrm{a}$ & $7.67 \mathrm{a}$ & - & $7.00 \mathrm{a}$ \\
\hline
\end{tabular}

${ }^{\mathrm{z}}$ Within a column, means followed by the same letter are not statistically different according to the least significant difference $(P=0.05)$.

${ }^{y}$ Plots receiving treatments in the spring only did not have fall applications; therefore, vegetation growing in those plots did not die during the fall of each study.

${ }^{\mathrm{x}}$ Treatments were not applied to control plots; therefore, vegetation growing in the control plots did not die.

containing AA can cause wilting and tissue discoloration within hours of application (Bingaman et al., 2000; Young, 2004), quickly leading to death of the aboveground vegetation. Others have reported similar results of AA controlling weeds quickly. Abouziena et al. (2009) found that $30 \%$ AA killed the leaves and shoots of sensitive weeds at early stages of growth within $2 \mathrm{~h}$ of application. Additionally, Evans et al. (2011) reported a high level of weed control with vinegar within the first day of treatment of weeds that were in the cotyledon to six-leaf stage at the time of application. Similar to the results of this study, several researchers have reported glyphosate to have $100 \%$ weed control $\approx 1$ week after application (Abouziena et al., 2008; Culpepper, 2006; Norris et al., 2001; Shaw and Arnold, 2002; Young, 2004).

Treatments were applied to subplots when the plot received a rating of 5 ; glyphosate, with both a fall application and a spring application, required reapplication at $82 \mathrm{~d}(2016)$ and $74 \mathrm{~d}$ (2017). In 2017, both $20 \%$ AA (80 d) and $30 \% \mathrm{AA}(77 \mathrm{~d})$ exhibited a similar number of days to the first reapplication (Fig. 1); therefore, they are comparable options for weed control for garden establishment. However, a spring-only application of $5 \% \mathrm{AA}$ resulted in the fewest number of days, $65.6 \mathrm{~d}$ (2016) and $61 \mathrm{~d}$ (2017), to receive a rating of 5 , implying that $5 \%$
$\mathrm{AA}$ is the least effective at reducing weed regrowth among these treatments. Hoffman and Regnier (2006) found similar results; they reported that the level of cover crop kill with vinegar $(5 \% \mathrm{AA})$ was less effective than glyphosate. Additionally, Abouziena et al. (2008) found glyphosate to be highly effective at controlling weeds in mandarin orchards compared with organic mulches, synthetic mulches, and cultivation, but they did not compare glyphosate to AA. Overall, when comparing treatments, applications of all treatments in both the fall and spring, compared with spring-only applications, required a similar number of days to the first retreatment (Fig. 1). This suggests that preapplication of weed control in the fall for garden establishment does not result in less weed competition in the summer.

In the subplots that did not receive retreatment applications, glyphosate outperformed all other treatments in 2017 , except $20 \% \mathrm{AA}$ (spring only), by lasting $105.3 \mathrm{~d}$ (fall/spring) and $117 \mathrm{~d}$ (spring only) before receiving a rating of 10 (100\% weed regrowth) (Fig. 2). All other treatments lasted at least $17 \%$ fewer days before receiving a rating of 10. In 2016, glyphosate (spring only and fall/spring) and 30\% AA (fall/spring) treatments did not result in full regrowth within the 132 $\mathrm{d}$ of the study and performed similarly to the other treatments, except 5\% AA and the control. In both studies, glyphosate, $30 \% \mathrm{AA}$, and $20 \% \mathrm{AA}$ required more days to fully regrow with weeds after the initial treatment applications (Fig. 2), suggesting that $5 \% \mathrm{AA}$ is not a suitable choice for controlling weed regrowth. These results are similar to those of Abouziena et al. (2009), Radhakrishnan et al. (2002), and Young (2004), who found 5\% AA to be less effective at controlling weed regrowth than higher concentrations of AA, especially for narrow-leaved weeds. There were no significant differences in the DAT to full regrowth between the fall/spring application and spring-only application of all treatments, suggesting that preapplication in the fall is not necessary.

The number of times plots received a rating of 5 and were retreated varied among treatment types. Glyphosate required one retreatment application each year (Fig. 3 ) and never received a rating of 5 again for the duration of each study. The 5\% AA 


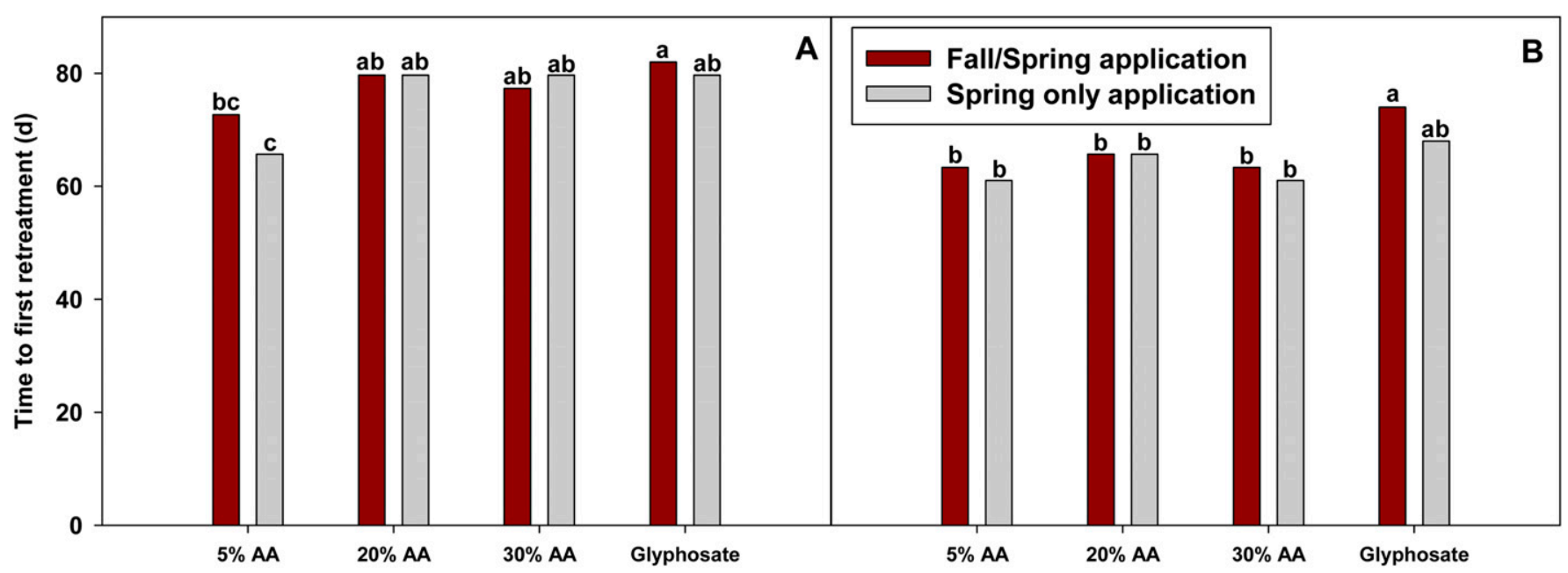

Fig. 1. Number of days after treatment until glyphosate (1.6\% a.i.), 5\% acetic acid (AA), 20\% AA, and 30\% AA were first reapplied to subplots when the plot received a quality rating of 5 (50\% weed regrowth) during the 2016 (A) and 2017 (B) studies comparing AA to glyphosate for weed suppression in Richmond, KY. Means followed by the same letter within each year are not statistically different according to the least significant difference $(P=0.05)$.

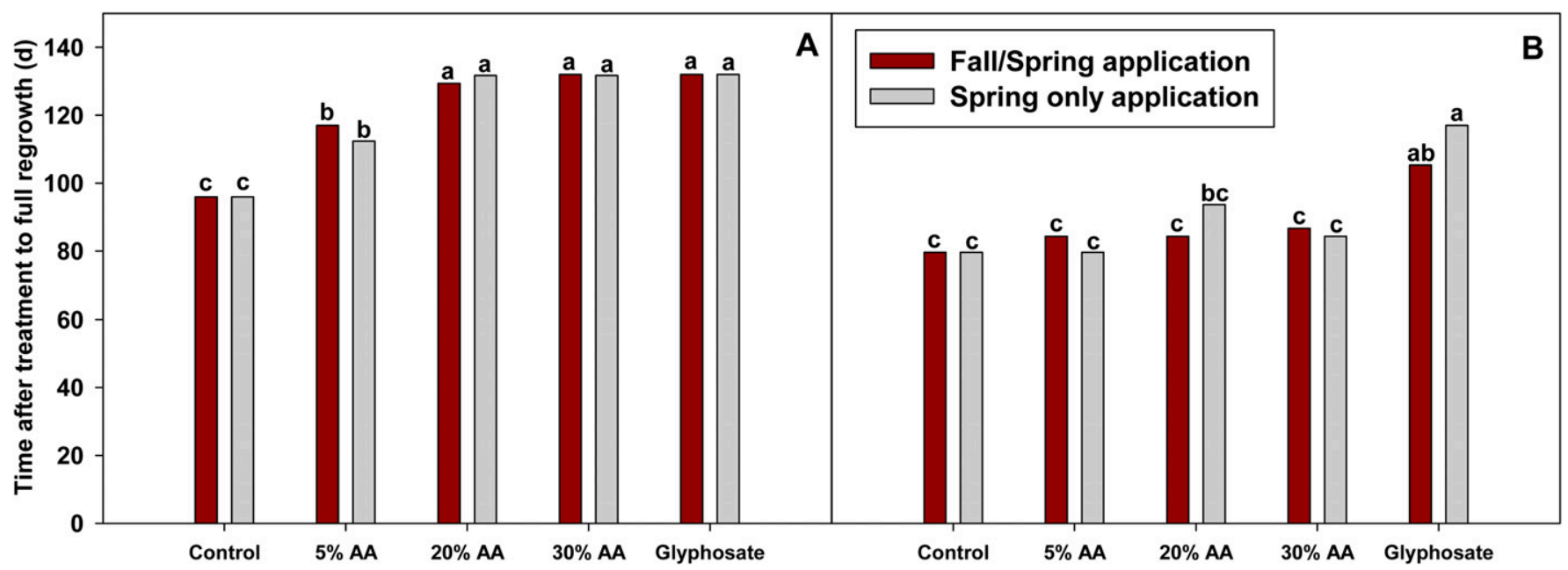

Fig. 2. Number of days after treatment until the glyphosate (1.6\% a.i.), 5\% acetic acid (AA), 20\% AA, and 30\% AA subplots received a rating of $10(100 \%$ weed regrowth) during the $2016(\mathrm{~A})$ and $2017(\mathrm{~B})$ studies comparing AA to glyphosate for weed suppression in Richmond, KY. Means followed by the same letter within each year are not statistically different according to the least significant difference $(P=0.05)$.

plots required more retreatment applications to subplots (five in 2016 and nine in 2017) compared with glyphosate plots (Fig. 3). Both $20 \%$ and $30 \%$ AA required between three (2016) and five (2017) retreatment applications (Fig. 3). Results indicated that glyphosate provides better long-term weed control than the vinegar options. This is likely due to the mode of action of glyphosate being systemic (Ragan and Massey, Inc., 2019), whereas AA is a contact herbicide that only kills the aboveground vegetation (Young, 2004). Higher concentrations of AA within the vinegar options appear to have better control of weeds than lower concentrations and might be a viable choice for controlling weeds in the garden throughout the growing season. Young (2004) reported similar results in a study comparing AA, glyphosate, pine oil, and plant essential oils for the control of weeds along roadsides. In this study, AA required four retreatment applications after the initial application and glyphosate only needed one retreatment application. There were no statistical differences between the fall/spring application and springonly application of all treatments, again suggesting that fall application is unnecessary for weed control before spring establishment of a vegetable garden.

\section{Conclusions}

Results indicated that glyphosate, when compared with $\mathrm{AA}$, is the more effective weed suppression method for garden establishment based on the number of DAT until full weed regrowth and number of retreatment applications throughout the studies. Although all three AA treatments (5\%, $20 \%$, and $30 \%$ ) initially eliminated weeds faster than glyphosate, AA did not control weeds for an extended period of time like glyphosate. Both 


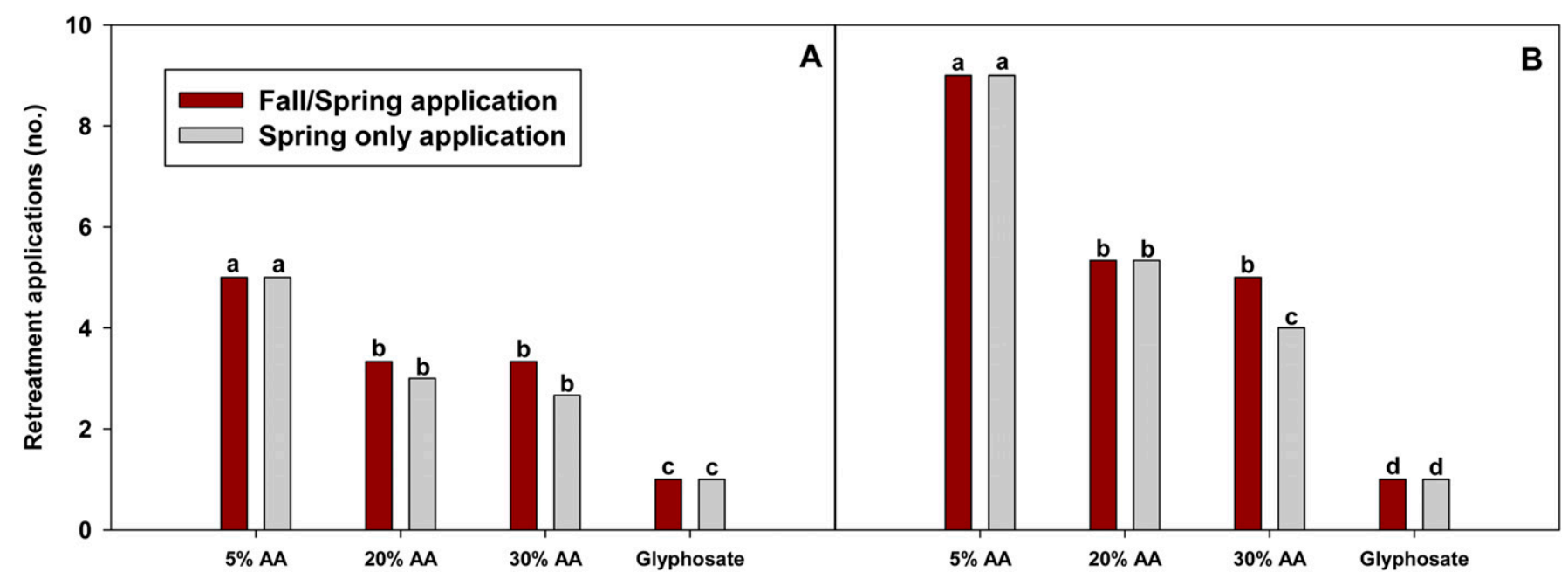

Fig. 3. Number of retreatment applications of glyphosate (1.6\% a.i.), $5 \%$ acetic acid (AA), $20 \%$ AA, and $30 \%$ AA needed for each subplot throughout the 2016 (A) and 2017 (B) studies comparing AA to glyphosate for weed suppression in Richmond, KY. Each time a subplot received a quality rating of $\geq 5$ (50\% weed regrowth), the subplot was retreated. Means followed by the same letter within each year are not statistically different according to the least significant difference $(P=0.05)$.

$20 \%$ and $30 \%$ AA are viable alternatives to glyphosate for commercial farmers or gardeners considering transitioning from conventional to organic, especially in cucurbit (Cucurbitaceae) or mulched gardens where there is reduced soil exposure. Results showed that preapplication of the weed-control treatments in the fall before garden establishment does not increase weed suppression during the growing season.

\section{Literature cited}

Abouziena, H.F., A.M. Omar, S.D. Sharma, and M. Singh. 2009. Efficacy comparison of some new natural-product herbicides for weed control at two growth stages. Weed Technol. 23:431-437.

Abouziena, H.F., O.M. Hafez, I.M. ElMetwally, S.D. Sharma, and M. Singh. 2008. Comparison of weed suppression and mandarin fruit yield and quality obtained with organic mulches, synthetic mulches, cultivation, and glyphosate. HortScience 43:795-799.

Allen, V.G., C. Batello, E.J. Berretta, J. Hodgson, M. Kothmann, X. Li, J. Mclvor, J. Milne, C. Morris, A. Peeters, and M. Sanderson. 2010. An international terminology for grazing lands and grazing animals. Grass Forage Sci. 66:2-28.

Bingaman, B.R., M.J. Howieson, and N.E. Christians. 2000. Alldown ${ }^{\mathrm{TM}}$ natural herbicide study. Turfgrass Res. Rpt., Iowa State Univ., Ames.

Bond, W. and A.C. Grundy. 2001. Nonchemical weed management in organic farming systems. Weed Res. 41:383-405.
Boyd, N.S., E.B. Brennan, and S.A. Fennimore. 2006. Stale seedbed techniques for organic vegetable production. Weed Technol. 20:1052-1057.

Brainard, D.C., W.S. Curran, R.R. Bellinder, M. Ngouajio, M.J. Vangessel, M.J. Haar, W.T. Lanini, and J.B. Masiunas. 2013. Temperature and relative humidity affect weed response to vinegar and clove oil. Weed Technol. 27:156-164.

Bruff, S.A. and D.R. Shaw. 1992. Tankmix combinations for weed control in stale seedbed soybean (Glycine max). Weed Technol. 6:45-51.

Buhler, D.D. and W.L. Werling. 1989. Weed control from imazaquin and metolachlor in no-till soybeans (Glycine max). Weed Sci. 37:392-399.

Culpepper, A.S. 2006. Glyphosate-induced weed shifts. Weed Technol. 20:277-281.

Evans, G.J. and R.R. Bellinder. 2009. The potential use of vinegar and a clove oil herbicide for weed control in sweet corn, potato, and onion. Weed Technol. 23:120-128.

Evans, G.J., R.R. Bellinder, and M.C. Goffinet. 2009. Herbicidal effects of vinegar and a clove oil product on redroot pigweed (Amaranthus retroflexus) and velvetleaf (Abutilon theophrasti). Weed Technol. 23:292-299.

Evans, G.J., R.R. Bellinder, and R.R. Hahn. 2011. Integration of vinegar for inrow weed control in transplanted bell pepper and broccoli. Weed Technol. 25:459-465.

Garrett, J.H. and C.M. Beck. 1999. Texas organic vegetable gardening. Lone Star Books, Lanham, MD.
Gianessi, L.P. and N.P. Reigner. 2007. The value of herbicides in U.S. crop production. Weed Technol. 21:559-566.

Griffith, G.M., J. Barrentine, and M.R. McClelland. 2006. Weed competition effects in Roundup Ready Flex cotton (Gossypium hirsutum L.). Proc. Beltwide Cotton Conf. 4-8 Jan. 2006. San Antonio, TX. Natl. Cotton Council, Memphis, TN. p. 2277-2280.

Hoffman, M.L. and E.E. Regnier. 2006. Contributions to weed suppression from cover crops, p. 51-57. In: H.P. Singh, D.R. Batish, and R.K. Kohli (eds.). Handbook of sustainable weed management. Food Products Press, New York, NY.

Kuepper, G. 2002. Organic farm certification and the national organic program. Appropriate Technology Transfer for Rural Areas (ATTRA) Rpt. No. IP232.

Malik, J.M., G.F. Barry, and G.M. Kishore. 1989. The herbicide glyphosate. Biofactors 2:17-25.

Moran, P.J. and S.M. Greenberg. 2008. Winter cover crops and vinegar for earlyseason weed control in sustainable cotton. U.S. Dept. Agr., Agr. Res. Serv./Univ. Nebraska-Lincoln Faculty Publ. 575. 19 June 2019. <http://digitalcommons.unl. edu/usdaarsfacpub/575>.

Morris, K.N. 2000. Guidelines for using NTEP trial data. Golf Course Mgt. 68:64-69.

Norris, J.L., D.R. Shaw, and C.E. Snipes. 2001. Weed control from herbicide combinations with three formulations of glyphosate. Weed Technol. 15:552-558. 
Patton, A. and D. Weisenberger. 2012. Efficacy of current organic postemergent weed control options in turfgrass systems, p. 26-30. In: 2011 Annu. Rpt. Purdue Univ. Turfgrass Sci. Program.

Peacock, L. and G.A. Norton. 1990. A critical analysis of organic vegetable crop protection in the U.K. Agr. Ecosyst. Environ. 31:187-197.

Radhakrishnan, J., J.R. Teasdale, and B. Coffman. 2002. Spray weeds with vinegar. 10 June 2019. <http://ars.usda. gov/is/pr/2002/020515.htm>.

Ragan and Massey, Inc. 2019. FarmWorks $41 \%$ glyphosate plus concentrate with surfactant grass and weed killer. 1 Nov. 2019. <https://raganandmassey. com/wp-content/uploads/2016/02/ fw_86068-4-84009_2_5gal.pdf $>$.

Rowland, M.W., D.S. Murray, and L.M. Verhalen. 1999. Full-season palmer amaranth (Amaranthus palmeri) interference with cotton (Gossypium hirsutum). Weed Sci. 47:305-309.

Shaw, D.R. and J.C. Arnold. 2002. Weed control from herbicide combinations with glyphosate. Weed Technol. 16:1-6.

Stopes, C. and S. Millington. 1991. Weed control in organic farming systems. Proc. Brighton Crop Protection Conf., Brighton, UK. p. 185-192.

Walz, E. 1999. Final results of the third biennial national organic farmers' survey.
Organic Farming Res. Foundation, Santa Cruz, CA.

Webber, C.L., M.A. Harris, J.W. Sherefler, M. Durnova, and C.A. Christopher. 2005. Vinegar as an organic burn-down herbicide. Proc. 24th Annu. Oklahoma and Arkansas Hort. Ind. Show, 14-15 Jan. 2005. Fort Smith, AR. p. 168-172.

Wilson, J.S. and A.D. Worsham. 1988. Combinations of non-selective herbicides for difficult to control weeds in no-till corn (Zea mays) and soybeans (Glycine max). Weed Sci. 36:648-652.

Young, S.L. 2004. Natural products for control of annual vegetation along roadsides. Weed Technol. 18:580-587. 